\title{
Is Stricter Regulation of Incentive Compensation the Missing Piece?
}

\author{
Larry D. Wall
}

\section{Working Paper 2019-6}

March 2019

\begin{abstract}
Although a number of steps have been taken to reduce the risk of financial stability, some significant weaknesses remain. This paper examines whether stricter regulation of incentive compensation is the missing piece needed to reduce risk to acceptable levels. Unfortunately, this review of the literatures on the relationship of risk to bank chief operating officer and bank employee compensation suggest both have some potential but that significant concerns remain in both cases. At this point, we cannot confidently say that compensation regulation is the missing piece.
\end{abstract}

JEL classification: G01, G21, G28

Key words: incentive compensation, bank regulation

https://doi.org/10.29338/wp2019-06

The author thanks the participants at the Banking Law Symposium 2018 at the University of Auckland held in honor of Professor David G. Mayes for helpful comments. The views expressed here are those of the author and not necessarily those of the Federal Reserve Bank of Atlanta or the Federal Reserve System. Any remaining errors are the author's responsibility.

Please address questions regarding content to Larry D. Wall, Research Department, Federal Reserve Bank of Atlanta, 1000 Peachtree Street NE, Atlanta, GA 30309-4470, 404-498-8937, larry.wall@atl.frb.org.

Federal Reserve Bank of Atlanta working papers, including revised versions, are available on the Atlanta Fed's website at www.frbatlanta.org. Click "Publications" and then "Working Papers." To receive e-mail notifications about new papers, use frbatlanta.org/forms/subscribe. 


\section{Is stricter regulation of incentive compensation the missing piece?}

\section{Introduction}

After the worst of the global financial crisis had passed, the G20 Leaders (2009) issued a statement in which they pledged to take various actions to strengthen the global financial system. ${ }^{1}$ In keeping with that statement, bank supervisors around the world have developed and are implementing a variety of international prudential regulatory standards. Moreover, in many cases the domestic regulators have adopted rules for their jurisdiction that are even stricter than those required by international agreements. As a result, almost all observers agree that the banking system is less prone to excessive risk taking than it was prior to the crisis. However, most independent analysts would also agree that the risk of a crisis remains too high. Thus, an important question is what are the missing piece or pieces of action needed to bring the level of risk down to an acceptable level.

Some of the most important regulatory steps taken since the crisis seek to limit banks’ risk exposure by imposing binding limits on banks' balance sheets. At the international level, the most significant changes are a package of revisions to Basel II capital adequacy requirements intended to address gaps identified during the crisis. Along with the revised capital requirements, Basel III also has provided the first international agreement establishing minimum liquidity requirements for banks. At the domestic level, some jurisdictions have imposed or are considering imposing rules that protect banks from "gambling" in securities markets with depositor funds.

\footnotetext{
${ }^{1}$ The reforms also included a discussion of improving the over-the-counter derivatives market.
} 
Although a good case can be made that on net the balance sheet restrictions have reduced the risk of the banking system, these restrictions have also created perverse incentives that tend to reduce the effectiveness of the regulations. One problem with some of these rules, especially the capital adequacy regulations, is that they result in banks optimizing their portfolios based on unavoidably flawed risk measures. The result of such optimization is that banks reduce their positions in areas where the regulations implicitly overestimate the risk and increase their positions where the regulations implicitly underestimate the risk. Moreover, banks do not stop at merely optimizing to the wrong risk measures; they have an incentive to find ways of complying with letter of the regulations while subverting the intent of the regulations, which is to engage in regulatory arbitrage. Finally, to the extent, banks cannot avoid the regulations; nonbank financial firms may be able to take market share by providing the services on terms that are not possible for the banks. This shift to nonbanks raises the potential that some nonbank firms who are outside the perimeter of prudential supervision may themselves become systemically important.

To the extent that perverse incentives undercut the effectiveness of balance sheet regulations, one alternative is to try to change banks incentives. Banks’ incentive to take excessive risk is due in large part to the existence of the government safety net: lender of last resort facilities, government deposit insurance, and other implicit government guarantees. One way of giving banks greater incentives to manage their risk is to scale back the safety net by developing resolution policies that force private investors to bear (almost) all of the losses when a bank fails. Recognizing the potential benefits of reform, the G20 Leaders (2009) also called for action bank resolution. Considerable progress has been made since 2009 towards developing credible resolution policies that force the private sector to absorb the losses without creating 
spillover to overall financial stability. However, the development of fully credible resolution policies is a tough legal and economic problem that has not yet been fully resolved. The most globally systemically important institutions operate in a wide variety of businesses and have large global footprints. The financial system benefits to the extent that these very large and complex banks help to integrate efficiently the global financial system. However, these banks’ size and complexity poses a variety of challenges, not the least of which is developing a method of resolving cross-border banks that will prove time consistent. A further problem is that resolving multiple systemically important banks at the same time is likely to prove far more difficult than resolving a single idiosyncratic failure at a time when the financial system is otherwise healthy.

Changes to resolution policies are not, however, the only way to change the incentives of bank decision makers. Bank shareholders may control the ultimate governance mechanism of banks, its board of directors. However, neither a bank's shareholders nor its board exercise direct control over the investment decisions that make a bank more or less risky. Rather, those decisions are made by bank's employees under the direction of the bank's chief executive officer (CEO). Thus, another way of changing the incentives that motivate bank decision makers is to change way that bank employees and CEOs are compensated.

Prior to the crisis, rules related to banks incentive compensation were largely missing from the regulators' toolkit. ${ }^{2}$ However, bonus payments to bankers during and after the crisis attracted considerable attention. Part of the problem in some circles was undoubtedly just envy

\footnotetext{
${ }^{2}$ To be sure, at least some of the regulators could take action. For example, U.S. bank supervisors have long had the authority to address any practice that they find is "unsafe or unsound.” Moreover, the mere threat of action may have been sufficient to discourage compensation schemes from too obviously encouraging highly risk activity. However, there were few, if any regulations, and no international standards of best practices.
} 
at the high levels of bankers' compensation. However, it also quickly became clear that bonus payments were not necessarily just a reward for a bank’s good performance; bankers were demanding large bonuses regardless of how their firm performed. ${ }^{3}$ Moreover, the Institute for International Finance (2009) found near unanimous agreement among the 37 banks in its survey (representing 57 percent of wholesale banking activity) that “compensation structures were one of the factors underlying the current crisis.”

Thus, it is not surprising that along with reforms to enhance capital and bank resolution, the G20 Leaders (2009) also expressed a determination to reform “compensation practices to support financial stability.” This call for action was anticipated by standards issued by the Financial Stability Forum (2009) and followed up by standards issued by the Forum’s successor, the Financial Stability Forum (2009).

The purpose of this paper is to analyze the potential for more effective regulation of banks’ incentive compensation systems to change risk-taking incentives and make the banking system more stable. The following section reviews the international principles and standards for incentive compensation. The Sections 3 and 4 review the literature on the effects of compensation on risk taking and on potential regulatory measures to better align incentives. In keeping with the way this literature is organized, the review is divided into Section 3 focusing on the CEO and Section 4 on the other bank employees that can have a material impact on the bank's risk exposure. The Section 5 evaluates existing regulatory requirements in light what we have learned from prior studies. The paper concludes with some thoughts about compensation in the evolving banking industry.

\footnotetext{
${ }^{3}$ See Murphy (2013).
} 


\section{Regulatory actions on incentive compensation}

The Financial Stability Forum (2009, hereafter FSF (2009)) provides 9 principles for sound compensation practices by “significant financial institutions” and the Financial Stability Board (2009, hereafter FSB (2009)) provides 19 standards for implementing those principles. The 9 principles are grouped under two headings focusing on process and one heading on the substance of compensation. The two process related headings include three principles for “Effective governance of compensation” and two principles for "Effective supervisory oversight and engagement by stakeholders.” The third principle under effective governance requires that the staff engaged in financial and risk control should be compensated independent of the business areas they oversee.

The remaining four principles are grouped together under the heading; "Effective alignment of compensation with prudent risk taking.” These four principles are based on the concept that compensation should take account of the risks that an employee takes on behalf of the firm, both prospective risks and those where outcomes been realized. These four principles (numbered 4-7) are:

4. Compensation must be adjusted for all types of risk.

5. Compensation outcomes must be symmetric with risk outcomes.

6. Compensation payout schedules must be sensitive to the time horizon of risks.

7. The mix of cash, equity and other forms of compensation must be consistent with risk alignment.

The 19 standards set out by FSB (2009) elaborate to varying degrees on both the process and substance of compensation, with 11 of the standards devoted to substantive issues. Standard 4 highlights the need to incorporate capital and liquidity risk in determining the size of firm’s 
incentive compensation pools and allocation of those pools. Standard 5 states that "subdued or negative financial performance" should lead to a "considerable" reduction in variable compensation, including both current and reductions in the amount previously earned compensation that is paid out.

Standard 6 discusses in greater detail the expectations for compensation payments to "senior executives as well as other employees whose actions have a material impact on the risk exposure of the firm." This brings under the standards both senior executives with firm-wide responsibilities and lower level employees whose performance may nevertheless have a material impact on the firm's risk exposure, such as business unit heads and even traders in security markets. Standard 6 requires that a substantial part of their compensation be variable and that 40-60 percent should be paid on a deferred basis with the proportion deferred increasing with the seniority of individual. Standards 7-9 require that this variable compensation be deferred over a period of several years and that the firm retains the right to reduce or eliminate the payments depending on realization of those risks via malus and/or clawbacks. These principles also encourage the use of equity or share-linked instruments that are likely to reflect long run value creation (or, one might add, value destruction). Standards 11, 12 and 14 seek to prevent firms and employees from adopting strategies that would undercut the effectiveness of deferred variable compensation requirements of Standards 6-9. ${ }^{4}$

The FSF (2009) principles and FSB (2009) standards have remained unchanged since their adoption and the focus of the FSB has shifted to monitoring their adoption by national supervisory agencies. In general, the FSB (2017) has determined that its members coming from

\footnotetext{
${ }^{4}$ Principle 10 requires that if "exceptional government intervention" is needed to stabilize the firm, that the supervisors will have the ability to restructure compensation. Principle 13 says significant financial firms should begin immediate adoption of the principles.
} 
developed countries have met the standards with the single exception of the United States (U.S.) disclosure requirements. Even here, the FSB acknowledges that much of the required information is publicly disclosed by U.S. banks. ${ }^{5}$

However, although the developed countries are in compliance, there are some significant variations in how different jurisdictions have implemented the principles. ${ }^{6}$ The European Union (EU) in particular has taken a more prescriptive approach, limiting variable compensation as a percentage of fixed compensation as a part of its Capital Requirements Directive IV. The general rule in the EU Directive is that the ratio variable compensation (bonuses) may not be exceed 100 percent of fixed compensation. However, a higher ratio may be permitted if shareholders approve (up to a ratio of 200 percent) and a discount of up to 25 percent may be applied for instruments deferred for more than five years. These restrictions apply world-wide to employees of banks with headquarters in the EU Europe and to the EU operations of banks with headquarters outside the EU.

These FSF (2009) principles and FSB (2009) standards, combined with national implementation efforts have had a significant impact on bank incentive compensation practices according to both anecdotal reports and limited empirical analysis. ${ }^{7}$ One benchmark for precrisis practices is the Board of Governors of the Federal Reserve System (2011) that discusses

\footnotetext{
${ }^{5}$ The U.S. federal banking agencies issued guidance on incentive compensation for banks in 2010 https:/www.federalreserve.gov/newsevents/pressreleases/bcreg20100621a.htm. The subsequent passage of the Dodd Frank Wall Street Reform and Consumer Protection Act in 2010 mandated the adoption of a joint rule by the banking agencies, along with the regulators of the credit unions, the housing government sponsored enterprises and broker-dealers. The agencies proposed a joint rule in in May of 2016 but have not given that rule final approval as of March 2019. https://www.federalreserve.gov/newsevents/pressreleases/files/bcreg20160502a2.pdf

${ }^{6}$ See http://www.nortonrosefulbright.com/knowledge/technical-resources/banking-reform/remunerationrequirements-for-banks---a-global-analysis/ for a review of 15 regulatory standards.

${ }^{7}$ The actual compensation paid senior management is publicly available for publicly traded firms in some countries. However, there are almost no publicly available information on the senior management contracts under which these payments were made nor on the compensation payments or contracts for material risk takers below the senior level.
} 
pre-crisis practices as well changes made by the covered banks in response to U.S. guidelines. Importantly, this report not only covered 16 U.S. domestic banks but also the U.S. operations of nine foreign banking organizations with a substantial presence in the U.S. and, thus, provides some information on a globally important banking organizations headquartered in a variety of jurisdictions. In terms of pre-crisis risk-adjustments, Board of Governors of the Federal Reserve Board (2011) states: “At the beginning of the horizontal review, no firm had a well-developed strategy to use risk adjustments and many had no effective risk adjustments.” Similarly concerning deferrals, the report states: "Deferring payouts was fairly common before the crisis, especially for senior executives and highly paid employees. However, pre-crisis deferral arrangements typically were not structured to fully take account of risk or actual outcomes.”

Since the adoption of the international compensation principles and standards, the Financial Stability Board has issued a series of progress reports on the implementation. Financial Stability Board (2017) provides as a high level overview that: "Supervisors assess the level of implementation by banking organizations reviewed for this report mostly as high, confirming the findings of previous reports.” Cerasi et al. (2012) provides some additional empirical evidence on the impact of the principles and standards. They find that banks in jurisdictions that have implemented the principles and standards tend to have compensation that is less linked to shortterm profits and more sensitive to risk than those in other jurisdictions.

\section{CEO compensation}

Bank CEOs have overall responsibility for their bank, including its risk exposure, and almost every decision they make is likely to have some consequences for their bank’s overall riskiness. This overall responsibility for their bank suggests that CEOs should be evaluated and compensated differently from other employees who have much more narrowly defined 
responsibilities. ${ }^{8}$ Moreover, this overall responsibility has important implications for both the theoretical and empirical literatures on bank incentive compensation that has contributed to most studies looking only at the CEO or only at the lower level employees. The theoretical difference is that equity-linked compensation may play an important role in aligning CEO’s incentives with shareholders whereas such compensation would be of limited help in aligning the interests of lower level employees who can only affect a small slice of the bank’s risk. Thus, most theoretical and empirical papers of CEO compensation explicitly study equity-linked compensation whereas studies of lower level employees do not look at equity-based compensation separately. On the empirical side, there is far more data for measuring both the CEOs’ performance and compensation. As the CEO has overall responsibility for the bank, performance can be measured using overall bank measures including stock performance and accounting earnings, both of which are publicly available. Further, given the importance of the CEO's role, some jurisdictions have long required firms to report on the CEO's ownership of the bank's stock and stock options, and to provide information on the amount of compensation paid. In contrast for lower level employees, banks typically only report compensation and performance aggregated to a very high level.

Given the importance of CEOs and in following with the literature, this section reviews the literature on bank CEO compensation. The first section reviews the theoretical literature and the second section reviews the empirical literature.

\footnotetext{
${ }^{8}$ The one group of employees that are arguably more similar to CEOs are the other senior executives in the so called C-Suite (that is chief operating officer, chief financial officer, and other executives with corporate wide responsibilities and titles starting with “chief”). The actions of these senior executives typically have a firm wide impact. However, exactly how much authority these other senior executives wield independent of the CEO varies from bank to bank and is not readily observable to external observers. As a result, almost all of the literature on bank senior management compensation and risk taking focuses on the firm's CEO_the one person with overall responsibility.
} 


\subsection{Theoretical literature}

A bank CEO's compensation package comes about from the negotiation between the bank's board of directors and the CEO. The theoretical literature on CEO compensation is almost entirely based on the assumption that the board is acting on behalf of the bank's shareholders to maximize the value of the bank's equity. These models typically also assume the CEO has complete control over the firm. Thus, the problem becomes how to incent the CEO to maximize shareholder value. Most of the theoretical models relating to CEOs focus exclusively on incenting the CEO to pick the value maximizing investment portfolio, but some also consider how to incent optimal effort by the CEO.

The first problem the equityholders and board face is determining what portfolio would maximize shareholder value. Here the banking literature can draw on a rich literature from corporate finance. That literature starts with the simple observation that if the firm is all equity financed then the optimal portfolio is the one with the highest risk adjusted returns. In this case, the most obvious way to align the CEO's interest with that of the shareholders is to make some part of the CEO's compensation dependent upon the value of the firm's equity. However, if the CEO is risk averse, the CEO will likely value the equity claim at a lower value than the more highly diversified shareholders. As a result, the optimal package will generally consist of a fixed salary plus some equity compensation.

The question of which portfolio maximizes shareholder wealth is more complicated if the firm issues risky debt—-that is debt which the firm will not be able to fully repay in all states of the world. In this case, the ex post shareholder value-maximizing portfolio may be more risky than the portfolio with the highest ex ante risk adjusted returns. The difference arises because the debtholders would bear part of the ex post losses if the portfolio suffers sufficiently large 
losses. However, the debtholders know ex ante that the firm may engage in risk shifting, that is pick the riskier projects, and as a result debtholders demand a higher interest rate to compensate for their increased risk of loss. Given that the owners cannot exploit the creditors ex ante, the equityholders would prefer to be able to commit to selecting the project with the highest ex ante expected returns and forgo their option of shifting to the riskier project. Thus, the boards of many corporations face two problems: how to mitigate the risk-shifting problem and what does that imply about CEO compensation.

Bolton, Mehran and Shapiro (2011) start with the intuition developed in the corporate literature but focus on banks. They analyze a simple model in which the bank's depositors and bondholders can observe the bank’s investment before they lend to the bank. In this case, the equityholders cannot exploit the bondholders by risk shifting and so prefer the portfolio with the highest return. However Bolton, Mehran and Shapiro (2011) show that the risk-shifting problem returns if the bank's bondholders cannot observe the choice of the project before buying the bank’s bonds. If the CEO's variable compensation arises solely from the bank’s equity, bondholders would correctly predict the bank would engage in risk shifting and demand a higher interest rate that compensated for the increased risk. One way of solving the risk-shifting problem and getting back to the first best outcome for the shareholders would be to commit to paying a compensation package to the CEO that takes full account of debtholder's losses, such as by making the CEO’s compensation depend in part on credit default swap prices set after the investments were made. In this case, the CEO will pick the highest value project even though it would be in the equityholders interest to take the riskier project after the bank has issued the bonds. Moreover, if the bank can credibly commit to basing CEO compensation in part on credit 
default swap values then the bondholders will correctly expect the bank to pick the lower risk portfolio and so will accept a lower interest rate.

Bolton, Mehran and Shapiro (2011) then bring in government deposit insurance for which the bank pays an insurance premium. If the insurance premium fully reflects the risk of the portfolio and the premium is set after the bank selects its investments, the shareholders will again prefer to compensate the CEO so that he selects portfolio with the highest expected overall value. However, if the premium is set in advance of bank's investment decision, the bank shareholders may prefer to structure the CEO's compensation such that it results in the selection of the riskier portfolio. Note, that in this case merely having risk-based premiums that are actuarially fair to the government is not sufficient to avoid creating an incentive to take the riskier project. If insurance premiums are set before the portfolio is selected, shareholders may benefit from selecting a riskier portfolio.

Thus, Bolton, Mehran and Shapiro (2011) suggest that equity based compensation may induce a bank CEO to engage in risk shifting. However, along with salaries and equity-based compensation, managers are also typically paid cash bonuses and provided with pensions. Importantly, executive pension plans are typically an unsecured obligation of the bank that has equal priority with other forms of debt in bankruptcy. As a result, these pension plans, along with other forms of deferred cash compensation, are sometimes referred to as "inside debt”.

Edmans and Liu (2011) analyze the use of bonuses, equity and inside debt in addressing two problems: incenting management to optimally exert more costly effort and to avoid incenting inefficiently large risk exposures. ${ }^{9}$ Their results suggest that the optimal compensation

\footnotetext{
${ }^{9}$ In their model, bonuses have a limited effect on the incentive to take excessive risk. The fact that bonuses are paid only if the firm is solvent discourages managers from increasing the risk of firm failure. However, conditional on
} 
package should include both equity to motivate greater effort and inside debt to reduce the incentives to take excessive risk. The split between equity and inside debt in their model depends upon the extent to which the value of the firm (debt and equity) is sensitive to the gains from managerial effort versus the losses due to excessive risk taking. The more important the potential losses from excessive risk taking, the greater the optimal proportion of inside debt.

Along with the above papers that analyze compensation policies in isolation to other bank regulations, there is a small literature examining the interaction of compensation regulation with other supervisory actions. Noe, Rebello and Wall (1996) study the interaction of compensation regulation with bank closure rules. Supervisory discretion in the areas of deposit insurance and lender of last resort facilities gives the regulatory agencies considerable discretion in determining whether and when a bank fails. Noe, Rebello and Wall (1996) define a late closure rule under which a bank will be closed if the market (or going concern) value of the bank is negative and an early closure rule where it is closed if the liquidation value is negative but the market value is still positive. In their model, a bank manager selects either a safe or a risky portfolio. The safe portfolio is less likely to be liquidation value insolvent but also has lower expected returns when the bank is market and liquidation value solvent. As a result, even though the safe asset has a higher expected value, shareholders may still prefer to incent their manager to select the more risky portfolio depending upon the parameter values. In Noe, Rebello and Wall's (1996) model, the supervisors can use their regulatory authority over managerial compensation to induce the manager to prefer the socially optimal lower risk portfolio.

the firm failing, the magnitude of its losses has a significant impact on the firm's creditors but not on management's bonuses. Hence, management will prefer risky assets that increase the expected value of payments in solvent state even if these assets also have lower payouts in bankruptcy 
John, Saunders and Senbet (2000) consider the interaction of deposit insurance premiums and incentive compensation. They note that neither the deposits nor the regulators can observe a bank’s investment opportunities. However, depositors and regulators can observe the contract offered by shareholders to bank management and they know that this contract determines the risk choices that are in the managers' self-interest. Given this information about management's risk choices plus other information (such as the level of the bank's capital), the deposit insurer in their model can set insurance premiums that exactly offset the insurer's expected losses and, thus, fully negate the risk shifting incentives created by deposit insurance. Moreover, given their assumptions, if the deposit insurer sets premiums that exactly offset its expected losses from bank failure, the result in John, Saunders and Senbet’s (2000) model will be that shareholders will offer a compensation contract that results in the manager picking the socially optimal risk exposure.

\subsection{Empirical literature}

Thus, theory suggests that bank shareholders may provide CEOs with equity-based compensation at least in part to encourage managers to exert more effort and take more risks, along with using inside debt to discourage excessive risk taking. Whether the boards of directors of banks use compensation policy to increase or decrease risk taking is unobservable as both the negotiations and the actual contract terms are generally not publicly available. However, U.S. bank holding companies are subject to Securities and Exchange Commission reporting requirements that includes information on both realized payments and CEO holdings of their bank's equity and options on that equity. A number of papers dating back to at least the 1990s examine the relationship between measures of the sensitivity of CEO compensation to firm performance. These studies have typically used data on stock and stock options to estimate the 
sensitivity of the CEOs' compensation to the level (delta) and variability (vega) of the firm's equity value and to the amount of inside debt held by the bank's CEO.

One prominent early paper from Houston and James (1995) studied banks over the period from 1984 to 1989 . They found little evidence that the compensation policies of the banks in their sample were designed to encourage CEOs to take more risk. However, looking at a later time period, 1992-2002, Mehran and Rosenberg (2008) found evidence that higher levels of option grants were associated with increased stock volatility (a measure of the riskiness of the bank).

A number of papers have found evidence that bank CEO incentive compensation led to increased risk taking during the period leading up to and including the crisis of 2007-09. DeYoung, Peng and Yan (2013), and Bai and Elyasiani (2013) observe that the vega of bank CEOs compensation increased in their samples from the mid-1990s to the early 2000s and then followed by a decline up to 2007 or 2008. Both papers estimate pooled time series-cross section models over a period from the 1990s to around the time of the start of the crisis. Both papers find that the more the CEO gained from increased risk taking (that is, their compensation had a higher vega), the more risky the bank became based on various accounting- and market-based risk measures. Moreover, both studies found evidence that the risk taking incentives were worse at the larger banks. DeYoung, Peng and Yan (2013) find that smaller banks moderated CEO risk taking incentives whereas they did not for the largest banks. Bai and Elyasiani (2013) find that the next to the largest size group in their sample increased vega the most.

Hagendorff and Vallascas (2011) also examine the impact of bank CEO’s compensation vega but focus on its impact on its impact on bank acquisitions. This approach focuses on only one of the ways a bank can take risk but it studies one of the decisions in which the CEO exerts 
disproportionate impact. Although CEOs are the most important determinant of a bank's risk exposure, in most cases they are not the only determinant with lower level officials also playing an important role. However, the CEO of an acquiring bank would generally be expected to have larger role in the acquisition of another bank. ${ }^{10}$ Hagendorff and Vallascas (2011) find that CEOs with higher vegas engage in mergers that resulted in the bank being more vulnerable to default (had a lower distance to default). As with the prior studies, they found evidence that this effect was greatest for the larger banks.

The financial crisis provided a chance to examine the impact of bank compensation policies on risk taking as revealed during a period of severe financial instability, which is precisely the sort of situation that is of greatest concern to prudential supervisors. Some studies found evidence that equity compensation could play a significant role. Fahlenbrach and Stulz (2011) found evidence that increased exposure to delta (equity returns) but not vega (equity risk) led to lower stock returns over the period from July 2007 to December 2008. Van Bekkum (2016) similarly found that delta was associated with larger losses but also lower measures of equity volatility and lower measures of overall risk over the July 2007 to March 2009 period. The coefficient on vega was consistently insignificant in his study. Bennett, Güntay, and Unal (2015) find that expected default probabilities went up and excess stock returns went down in their estimation of models that have either with delta or vega between January 2007 and December 2008.

Chesney, Stromberg, and Wagner (2018) argue that the standard measures of delta and vega do not accurately measure the incentive of CEOs to select riskier assets because they ignore

\footnotetext{
${ }^{10}$ At a minimum, it is rather unlikely that an acquisition would be made over the objections of the acquiring bank's CEO.
} 
the effect of financial leverage. That is, the change in equity value and volatility from selecting an asset depends not only on the asset's return and volatility, but also on the firm' debt to equity ratio. Higher leverage ratios result in greater expected returns to equityholders as well as greater volatility. Chesney, Stromberg, and Wagner (2018) take a sophisticated options based approach to adjusting the CEO’s delta and vega for their firm’s leverage. They find that their adjusted delta and vega measures are significantly better predictors of write-downs during the crisis than the usual delta and vega measures. They obtain similar results using other risk measures, such as distance to default.

Although the above studies find some evidence for delta and vega the evidence is not consistently supportive of either. Moreover, almost all of the evidence supporting delta and vega goes away when the studies add some measure of inside debt. Fahlenbrach and Stulz (2011) and Chesney, Stromberg, and Wagner (2018) do not use a measure of inside debt. However, Van Bekkum (2016) and Bennett, Güntay, and Unal (2015) find that in their models with inside debt, delta and vega that only the coefficient on inside debt is statistically significant. Tung and Wang's (2011) find generally similar results across a wide range of risk measures, their measure of inside debt (CEO debt-equity ratio) is significantly negatively correlated with risk and other adverse outcomes, while their variables measuring delta and vega are insignificant. The sole exception is that bank bond returns are significantly positively correlated with delta, significantly negatively correlated with vega and not correlated with the CEO debt-equity ratio (when all three CEO incentive measures are in the same equation). Also, Bolton, Mehran and Shapiro (2011) find evidence that inside debt is negatively correlated with cumulative CDS spread changes after the SEC required enhanced reporting of deferred compensation and pensions in 2007. 
Thus, prior studies provide at best conflicting evidence on the hypothesis that CEO equity based contribution was a significant contributing factor to the crisis. Fahlenbrach, Prilmeier and Stulz (2012) raise further questions about the role of CEO compensation causing the crisis. They compared the performance of banks in the 1998 financial crisis with that during the period from July 2007 to December 2008. The 1998 financial crisis was marked by Russia defaulting on its debt along with LTCM's collapse and near failure. Their results suggest that for every percentage point in loss of equity value in 1998, the bank lost 66 basis points during the financial crisis. Given the difficulty in evaluating the ex-ante risk of the asset portfolios, they cannot exclude the possibility that the worst hit banks in 1998 tried to shift to asset portfolios that has less ex ante risk in 2007. However, they do observe that funding risk, leverage and asset growth rates were positively correlated between the two period. Additionally, they find some weaker evidence that the banks worst hit in the September 1987 stock market crash were took larger losses in 2007-08 and were more likely to fail during 2007-09. Fahlenbrach, Prilmeier and Stulz's (2012) methodology does not allow them to empirically identify the link between the two periods. However, their preferred hypothesis is that individual bank's risk exposure is primarily determined by its risk culture and this culture changes only very slowly over time. Another, not mutually exclusive, hypothesis is that the shareholder value maximizing risk position of a bank depends upon two factors that may be highly persistent: the bank's core competencies and its customer base.

Hagendorff, Saunders, Steffen and Vallascas (2017) more directly address the relative importance of a bank's CEO in determining risk exposures. They first compare observable CEO characteristics and compensation variables with bank fixed effects in determining bank business policies. Their analysis includes measures of delta, vega and cash bonuses, but not inside debt. 
They find that their compensation variables combined with their CEO attribute variables (such as age, gender, and holds an MBA) explained almost none of the eight business policy variables in their model (such as loans to deposits, derivatives usage, and non-deposit funding). They find that vega explained some measures of equity returns and risk over the July 2007 to December 2008 period. However, the addition of these variables along with a variety of other controls added almost no explanatory power to their model relative to a model with only firm fixed effects. These results support Fahlenbrach, Prilmeier and Stulz’s (2012) in suggesting that variations in risk exposure are more being driven by long run factors than by compensation.

Given the inability of observable management characteristics and incentive compensation to explain bank’s risk exposure, Hagendorff, Saunders, Steffen and Vallascas (2017) test the hypothesis that there is some unobservable manager specific effects. Their results indicated these manager specific effects (or styles) were related statistically and economically significantly to bank risk taking. They conclude that regulatory efforts to constrain executive compensation is likely to only have a minor effect on bank business models and risk taking.

\section{Bank employees}

The literature on bank employee compensation and bank risk can be broken into two literatures. A small mostly empirical literature on whether banks’ incentive compensation policies have a significant impact on bank risk taking which is reviewed in the first subsection. The second literature, which analyzes optimal regulation of bank employees’ incentive compensation, is reviewed in the second section.

\subsection{Employee incentive compensation and their risk taking}

Very few papers study the overall effect of bank employee compensation on the bank's risk taking, likely due to the data limitations. One feasible empirical approach is to focus on 
what is publicly available, aggregate data on compensation and overall bank performance. Acharya, Litov, and Sepe (2013) take bank-wide perspective focusing on the relationship of overall compensation of non-executive employees to total interest income and net interest income their sample of publicly traded banks. They find that compensation was more highly correlated with total interest income than with its net value. They also find that the more sensitive compensation is to total interest income, the higher the value of their stock return based risk measures during the crisis.

An unavoidable problem with using data aggregated to the bank level is that it can only recognize correlations in the data, identifying a causal relationship between compensation and risk taking is not possible. One way around this is to obtain nonpublic data on compensation that permits the use of various empirical identification strategies. Efing, Hau, Kampkötter, and Steinbrecher (2015) do this at the bank level in their study of the effect of cash bonus payments on bank risk. They have bonus payments broken down by business segment and level within each bank’s hierarchy for a sample of 67 banks in Austria, Germany and Switzerland from 2003 to 2007. They first find that the use of incentive pay is positively correlated with the level and volatility of bank trading income. Efing, Hau, Kampkötter, and Steinbrecher (2015) then seek to address the identification problem by using overall bonuses paid by the bank as instrument to address the possibility that higher levels of trading income cause higher bonuses. They find that their results still hold, overall bonuses are positively correlated with the level and volatility of trading income.

An alternative to examining overall risk is to focus on the risk of a specific part of the bank. Such an approach sacrifices some generality but allows for more in-depth analysis and better identification. Three papers in particular have focused on the mortgage lending area. 
Inderst and Pfeil (2013) provide a theoretical analysis of incentive compensation in mortgage lending for both loans retained in portfolio and those securitized. The more relevant portion of their analysis for our purposes relates to the loans held in portfolio. They show that bonus payments based on volume of loan production results in the lending officer withholding any private information they may have acquired on the quality of the borrower. As a result, such volume-based bonuses result in higher losses than would occur if the bonus were delayed until the bank had more information about the borrower's quality.

Two empirical papers, Tzioumis and Gee (2013) and Agarwal and Ben-David (2017) study the potential for production based incentives to induce increased risk taking by mortgage lenders in the U.S. Some banks provide bonuses based on the volume of mortgage loans made by an individual lender in a month with some minimum amount (or value) of the new loans needed to qualify for the bonus. These bonuses can incent increased effort on the part of the lenders. However, these incentives can also create incentives for loan officers to try to book more mortgage loans at month end in order to hit their bonus target. Both studies found that mortgage-lending officers increased their volume of lending near month end. They also found that loans originated on the last day of the month have a higher likelihood of delinquency or default. In both of these studies, the identification is provided by the plausible assumption that the day of the month does significantly affect the quality of loans available to the loan officer.

\subsection{Regulating employee compensation}

An issue with bank employee compensation is why any regulation is needed at all. Absent some other market failure, no regulation would be needed if the shareholder value maximizing risk position is the same as the socially optimal level or even if the bank’s CEO (and other senior executives) incentives were aligned with the socially optimal position. One possible 
response is that neither shareholders’ nor CEOs’ incentives are perfectly aligned, so some regulation of employees may be optimal. Several papers explore another, not mutually exclusive, potential market failure that could justify regulation-competition in the market for bank employees.

The large bonuses paid by banks that continued even through the early phases of the crisis provoked widespread criticism. In response, senior bankers argued that competition for the best staff forced them to pay large bonuses for some positions. Tett (2009) reports that "As one banker says: ‘These bonuses are crazy—we all know that. But we don’t know how to stop paying them without losing our best staff."”

Thanassoulis (2012) observes that the total remuneration bill at some investment banks prior to the crisis reached 50 percent of shareholder equity value and in the prior decade had gotten as high as 80 percent of shareholder value. Thus, he argues that the total amount of compensation paid was by itself a major risk factor. In order to focus on the level of compensation, Thanassoulis (2012) develops a model in which bonuses are not needed to incentivize work, bankers may not engage in risk shifting and all of the participants are risk neutral. In his model, teams of bankers can be ranked from highest to lowest skill based on their ability to generate returns from their investment decision. As a result, the better teams are worth more to the larger banks as the larger banks can give these bankers more assets to manage. Given the assumption that everyone has complete information, the result is that the winning bank for any given team of bankers must bid at least as much as the next smallest bank bids would bid for the team. Thanassoulis (2012) views that result as a market failure in that banks do not take account of the effect of their compensation bids on the profitability of other banks. 
In Thanassoulis (2012) any regulatory restrictions on compensation would take the form of restrictions on bonuses as banks prefer to pay bonuses. Although all of the agents in his model are risk neutral, the bank may be subject to costly runs if its intermediate value falls to too low of a level. The risk of such a run can be reduced if the bank pays bonuses that can be reduced when bank asset values are low. The ideal regulation in his model would be a bank specific bonus cap that would reduce competition for teams of bankers. ${ }^{11}$ However, he observes that in his model a strict cap on bonuses will not prevent competition but rather shift the competition to higher fixed salaries. The result will be the worst of two worlds, competition in the labor market will continue force compensation up and that compensation will take a form that cannot be reduced when asset values are low.

Bannier, Feess, and Packham (2013) develop a model in which banks also compete for bankers of varying quality but in their model the bankers can pick safe or risky assets. The high quality bankers in their model are able to identify higher expected return projects regardless of whether they are safe or risky. Banks pay bonuses because this form of compensation has a higher expected value to high quality employees resulting in a separating equilibrium where only high quality employees taking the bank’s job offer. However, the bank cannot observe how the employee allocates funds between safe and risky investments, and thus must pay bonuses based on overall observed performance. The problem arises from banks' competition for the employees with banks offering larger bonuses to attract the best employees. The potential for earning higher bonuses induces the workers to pick a higher risk portfolio than would be optimal for the bank. Thus, competition for employees in the Bannier, Feess, and Packham (2013) model

\footnotetext{
11 Thanassoulis (2014) proposes a bank specific cap on total compensation paid as a fraction of the bank's risk weighted assets.
} 
not only induces higher overall compensation but also does so in a way that motivates the workers to take excessive risk.

Thus, there is some theoretical basis for regulating bonus payments to workers. However, theoretical analysis of regulating bonuses also provides an important warning; poorly conceived bonus payment rules could increase rather than decrease bank risk. Thanassoulis (2012) analysis of the impact of limiting total bonus payments is one example of such limits may increase risk. Two other papers show how applying parts of the seemingly common sense FSB Principles and Standards could also result in worse outcomes.

The Principles and Standards call for the compensation of bank risk managers to be independent of the performance of the business lines. Kupiec (2013) analyzes a model in which risk managers work engage in costly efforts to reduce the probability of default and loss given default. A bank optimally offers these workers incentives to engage in loss mitigation activities. However, Kupiec (2013) observes that the provision of mispriced deposit insurance would induce banks to provide suboptimal amounts of incentive compensation. He further argues that the existing regulatory guidance in the U.S. discourages linking risk managers' compensation to the performance of the loans which is the exact opposite of optimal policy.

The Principles and Standards also call for the reduction of bonus pools when a bank is performing poorly. Jarque and Prescott (2013) analyze such a requirement in a model where individual bankers have some control over the correlation of the returns of their portfolio of assets with the returns on the rest of the bank's portfolio. The problem they find is that such a requirement may encourage employees to pick portfolios that are more highly positively correlated with asset returns in a bank's portfolio. If the banker picks a portfolio that is highly correlated and that portfolio does well, likely the rest of the bank is doing well and the banker 
receives the full bonus she has earned. However, if the worker selects assets that do well when the rest of the bank is doing poorly, the employee is likely to receive a smaller bonus because the bank has a smaller bonus pool. Thus, the result of reducing bonus pools when a bank does poorly is that individual bankers are likely to be discouraged from reducing the bank's overall risk by diversifying the its risk exposure.

\section{Is stricter regulation the missing piece?}

The principles in FSF (2009) which were adopted and elaborated on by the standards in FSB (2009) have had a significant impact on bank compensation practices. However, a number of studies conducted since those principles and standards were promulgated have enhanced our understanding of incentive compensation. Thus, an important set of questions are: (a) do the studies suggest ways that existing principles and standards could be enhanced, and (b) could stricter compensation guidelines be the missing piece in lowering the risk of financial instability. The following two sections address these questions from the perspective of CEO compensation and other bank employee compensation.

\subsection{CEO compensation}

Studies focusing on equity-linked compensation provide mixed evidence of a correlation with risk taking but on balance appear to suggest a positive correlation. However, several studies that also include the CEOs' pre-crisis holdings of inside debt raise doubts about the strength of this correlation. These studies find that when measures of delta, vega and inside debt are included in the same estimation equation, only inside debt has significant explanatory power. Moreover, the correlations in those studies are as predicted, higher levels of inside debt are correlated with reduce risk taking. Taken at face value, these results suggest that one way of strengthening the incentive compensation rules may be to deemphasize the use of equity linked 
compensation in the regulatory requirements and instead require banks to rely more on the use of inside debt.

However, other work since the crisis raises questions about the direction of causality. Are compensation policies and bank risk correlated because differences in compensation policies cause CEOs to have their bank take more risk? Or do persistent differences in bank business models and risk culture cause cross-sectional differences in CEO compensation and bank risk exposure. Fahlenbrach, Prilmeier and Stulz’s (2012) finding that cross-sectional differences in bank performance during the crisis could be predicted by differences in performance decades earlier suggest that the causality does not run from CEO compensation policies to risk taking decisions. Further, work by Hagendorff, Saunders, Steffen and Vallascas (2017) suggest that to the extent CEOs influence risk decisions, the nature of that influence may be more driven by not readily observable CEO characteristics rather than by the CEO’s incentive compensation.

Overall, the literature appears to have two implications for regulating CEO compensation. First, the bias in the existing regulations towards equity-linked compensation should be reconsidered. The literature suggests that inside debt is a more effective way of incenting CEOs to take less risk. Second, the available evidence suggests we should be modest in our expectations for what changes in incentive compensation can do to reduce bank risk taking. The extent to which CEO compensation policies cause bank risk taking policies versus the extent to which both compensation and risk are determined by third factors has not been clearly established. The existence of two studies raising doubt about the extent to which compensation policies cause risk-taking policies is not sufficient to justify repealing the CEO compensation regulations, especially given the economic logic suggesting some link should exist. However, these studies in combination with methodological weaknesses in prior studies means that we 
cannot confidently state that stricter compensation regulation is the missing piece that will help us significantly reduce banks’ risk exposure.

\subsection{Employee compensation}

The implementation of the FSF (2009) principles and FSB (2009) standards have changed the compensation practices of bank employees who can expose their organizations to material risks. In order to evaluate what further changes should be made, it would be helpful to consider three questions about what has already been done: (a) what actions are supported by the evidence, (b) what actions do we lack sufficient evidence to evaluate the changes, and (c) where does the evidence suggest that changes may cause more harm than good.

The most important action supported by the available evidence is simply the decision to include all material risk takers with the scope of the standards and principles. One could argue that bank supervisors need not worry about bank employee compensation policies so long as the bank CEO has the correct incentives. However, this argument appears flawed on at least two grounds. First, it is not clear that the existing principles and standards provide bank CEOs with the right incentives or that even providing the right incentives to CEOs would be sufficient given the persistence of other factors such as risk culture and customer bases. Second, theoretical studies provide reason to be concerned that competition in the market for bank employees may lead to riskier banks. Moreover, although the empirical literature relating bank employee compensation to risk taking is rather small, these studies have found consistent evidence of a causal link between employee compensation policies and increased risk taking by bank employees in the cases studied.

One of the most important areas where we lack evidence about the effectiveness of the principles and standards is that of the requirement that compensation payments be sensitive to 
the time horizon of the risks. The large banks have generally adopted policies that require the deferral of bonuses of material risk takers and expose those bonuses to malus and/or clawback. However, there is almost no evidence on the effectiveness of these provisions, likely due in large part to the fact these changes are relatively new and, in most cases, the banks have not experienced the sort of losses that would trigger malus and/or clawback provisions. Moreover, the existence of provisions allowing malus and/or clawbacks is a necessary but not sufficient condition for these to effect employee risk taking. Whether and how the provisions are implemented will also play an important role in whether these provisions deter excessive risk taking. Thus, the area of malus and clawbacks is one that merits continued monitoring both in terms of how these provisions are implemented and in terms of how effective they are in deterring risk taking.

Although we have little empirical evidence suggesting ways the changes are doing more harm, the theoretical literature raises three concerns. First, Kupiec’s (2013) analysis raises questions about whether and in what circumstances the risk manager's bonuses should be independent of the business lines. Second, Jarque and Prescott (2013) raise a more fundamental question about policies linking bonus pools for one individual or line of business to the performance of other individuals or lines of business. Such practices may increase overall bank risk by encouraging employees to follow risk taking practices that are more highly correlated with their colleagues.

The third concern relates specifically to the EU cap on bonus payments relative to base salary. Such a cap would be one way of responding to concerns about excess competition for bank employees and may dampen the risk taking incentive created by excessive bonuses in Bannier, Feess, and Packham (2013). However, such a cap seems rather crudely designed to 
address the risk taking incentives problem with the cap limits likely too high to be effective for some employees and unnecessarily low for others resulting in reduced effort. Moreover, as Thanassoulis (2012) observes, such a cap will not necessarily prevent banks from bidding up the compensation paid to key employees. Rather the effect of the cap will be to reduce the banks' ability to reduce their expenses during economically challenging periods. ${ }^{12}$

The bottom line on the lessons from the literature for regulating employee compensation is in many ways similar to that for bank CEOs. There is a solid case for continuing the regulation but we lack the basis for viewing enhanced incentive compensation regulation as the missing piece needed to reduce banking system risk to acceptable levels. Indeed, the literature suggests that the first issue to be considered are places where the existing principles and standards, and in some cases the implementation of compensation regulation went too far. Additionally, we should seek to expand our understanding of malus/clawbacks by monitoring their implementation and studying their effectiveness.

\section{Conclusion}

The banking system is generally more stable than it was prior to the crisis but more work remains to enhance stability. As the limitations of some changes become clearer, such as those related to bank capital and resolution, the potential for other ways of strengthening the financial system should be considered. This review of bank incentive compensation suggests that considerable progress has been made since the crisis towards making the compensation paid individual bank CEOs and employees more sensitive to the risk exposures generated by their activities. However, post-crisis analysis of the theoretical and empirical consequences of

\footnotetext{
12 See also Murphy (2013) for a discussion of the potential problems created by the EU limits on bank bonus payments.
} 
incentive compensation guidelines raise a variety of questions related to their effectiveness and unintended consequences. At this point, the preponderance of the evidence argues in favor of continuing supervisory guidelines for bank compensation but against looking to such regulation to provide the missing piece.

The analysis discussed in this paper, however, suffers from one important limitation. Both the theory and empirical analysis focuses on the banking system as it has been in the last several decades. However, the business of banking has always been about obtaining, storing, processing and analyzing information. As the cost of these processes has come down, so has the distinctiveness of the boundary between banks and nonbank financial firms. Now the continuing declines in the cost of obtaining and using information are starting to erode the boundary between banks and information technology firms. This erosion has become especially apparent in areas related to analyzing data with ongoing advances in big data and machine learning. Further, the development of distributed ledger technology (including blockchains) threatens to speed dramatically the rate of erosion in areas related to information storage and record keeping. Indeed, some senior bankers are starting to think of the firms they run as more technology firms than as financial firms.

Viewing banks as technology companies has a variety of implications for bank compensation and financial stability, a full review of which would go far beyond the scope of this paper. However, two points can be made that will help to highlight what is at stake. ${ }^{13}$ First, to the extent that banking is inescapably becoming a technology business, we cannot limit our analysis of the bank employees' labor markets to competition among banks. Banks may be

\footnotetext{
${ }^{13}$ For some discussion of the regulatory implications of developments in big data, machine learning and artificial intelligence see Wall (2019) and Jagtiani, Wall and Vermilyea (2018).
} 
major players in the markets for technology talent but they are by no means the only ones competing for tech employees nor are banks necessarily the employers with the deepest pockets. ${ }^{14}$ Second, the phrase "move fast and break things" that is sometimes attributed to technology firms is a scary concept when applied to firms and markets that play critical roles in maintaining financial stability. Ongoing developments in the technology area are not going to eliminate the need for thoughtful bank regulation for the foreseeable future.

\footnotetext{
${ }^{14}$ Martin and Beesley (2016) report on BBVA's concern about its ability to recruit technology staff given the EU's
} limits on bonus payments. 


\section{References}

Acharya, Viral V., Lubomir V. Litov, and Simone M. Sepe (2013). Non-Executive Incentives and Bank Risk-Taking, Working Paper, New-York University. (accessed March 19, 2019) http://www.u.arizona.edu/ litov/NonExecIncentivesBankRisk.pdf.

Agarwal, Sumit and Ben-David, Itzhak (2017). Loan Prospecting and the Loss of Soft Information Journal of Financial Economics 129, no. 3: 608-628.

Arnold, Martin and Arthur Beesley (2016). Spanish bank BBVA warns bonus cap hurts tech push. Financial Times (August 21). (accessed March 19, 2019) https://www.ft.com/content/66c75f74-6790-11e6-ae5b-a7cc5dd5a28c

Bennett, Rosalind L., Levent Güntay, and Haluk Unal (2015). Inside debt, bank default risk, and performance during the crisis. Journal of Financial Intermediation 24, no. 4: 487-513.

Bai, Gang, and Elyas Elyasiani (2013). Bank stability and managerial compensation. Journal of Banking \& Finance 37, no. 3: 799-813.

Bannier, Christina E., Eberhard Feess, and Natalie Packham (2012). Competition, bonuses, and risk-taking in the banking industry. Review of Finance 17, no. 2: 653-690.

Board of Governors of the Federal Reserve System (2011). Incentive Compensation Practices:

A Report on the Horizontal Review of Practices at Large Banking Organizations. (accessed March 19, 2019) https://www.federalreserve.gov/publications/otherreports/files/incentive-compensation-practices-report-201110.pdf

Bolton, Patrick, Hamid Mehran, and Joel Shapiro (2015). Executive compensation and risk taking. Review of Finance 19, no. 6: 2139-2181.

Cerasi, V., Deininger, S., Gambacorta, L., \& Oliviero, T. (2017). How post-crisis regulation has affected bank CEO compensation, Bank for International Settlements Working Papers No 630. (accessed March 18, 2019) https://www.bis.org/publ/work630.pdf.

Chesney, Marc, Jacob Stromberg, and Alexander F. Wagner (2018). Managerial incentives to take asset risk. University of Zurich NCCR FINRISK working paper 607. (accessed March 18, 2019) https://www.nccr-finrisk.uzh.ch/media/pdf/wp/WP607_B1.pdf

DeYoung, Robert, Emma Y. Peng, and Meng Yan (2013). Executive compensation and business policy choices at US commercial banks. Journal of Financial and Quantitative Analysis 48, no. 1: 165-196.

Edmans, Alex, and Qi Liu (2010). Inside debt. Review of Finance 15, no. 1: 75-102. 
Efing, Matthias, Harald Hau, Patrick Kampkötter, and Johannes Steinbrecher (2015). Incentive pay and bank risk-taking: Evidence from Austrian, German, and Swiss banks. Journal of International Economics 96: S123-S140.

Fahlenbrach, Rüdiger, Robert Prilmeier, and René M. Stulz (2012). This time is the same: Using bank performance in 1998 to explain bank performance during the recent financial crisis. The Journal of Finance 67, no. 6: 2139-2185.

Fahlenbrach, Rüdiger, and René M. Stulz (2011). Bank CEO incentives and the credit crisis. Journal of Financial Economics 99, no. 1: 11-26.

Financial Stability Forum (2009). FSB Principles for Sound Compensation Practices (accessed March 19, 2019) http://www.fsb.org/2009/04/principles-for-sound-compensationpractices-2/.

Financial Stability Board (2009). FSB Principles for Sound Compensation Practices: Implementation Standards (accessed March 19, 2019) http://www.fsb.org/2009/09/principles-for-sound-compensation-practicesimplementation-standards/.

Financial Stability Board (2017). Implementing the FSB Principles for Sound Compensation Practices and their Implementation Standards (July 4). (accessed March 19, 2019) http://www.fsb.org/2017/07/fsb-publishes-progress-report-on-implementation-ofcompensation-standards/

G20 Leaders (2009). G20 Leaders Statement: The Pittsburgh Summit (24-25September). (accessed March 19, 2019) http://www.g20.utoronto.ca/2009/2009communique0925.html.

Institute of International Finance (2009). Compensation in Financial Services Industry Progress and the Agenda for Change.

Hagendorff, Jens, and Francesco Vallascas (2011). CEO pay incentives and risk-taking: Evidence from bank acquisitions. Journal of Corporate Finance 17, no. 4: 1078-1095.

Hagendorff, Jens and Anthony Saunders, and Sascha Steffen, and Francesco Vallascas (2017). The Wolves of Wall Street: Managerial Attributes and Bank Business Models (June 12). (accessed 18 March 2019) https://ssrn.com/abstract=2670525 .

Houston, Joel F., and Christopher James (1995). CEO compensation and bank risk Is compensation in banking structured to promote risk taking?. Journal of Monetary Economics 36, no. 2: 405-431.

Inderst, Roman, and Sebastian Pfeil (2012). Securitization and compensation in financial institutions. Review of Finance 17, no. 4: 1323-1364. 
Jagtiani, Julapa, Larry Wall, and Todd Vermilyea (2018). The Roles of Big Data and Machine Learning in Bank Supervision. Banking Perspectives The Clearing House (First Quarter). (accessed March 19, 2019) https://www.theclearinghouse.org/bankingperspectives/2018/2018-q1-banking-perspectives/articles/big-data-ml-bank-supervision

Jarque, Arantxa and Edward S. Prescott, (2013). Banker Compensation and Bank Risk Taking: The Organizational Economics View. FRB Richmond Working Paper No. 13-03. (accessed March 19, 2019) https://ssrn.com/abstract=2228910.

John, Kose, Anthony Saunders, and Lemma W. Senbet (2000). A theory of bank regulation and management compensation. Review of Financial Studies 13, no. 1: 95-125.

Kupiec, Paul (2013). Incentive Compensation for Risk Managers When Effort is Unobservable. AEI Economic Policy Working Paper 2013-07. (accessed March 19, 2019) https://ssrn.com/abstract=2344907.

Mehran, Hamid and Joshua V. Rosenberg (2008). The effect of employee stock options on bank investment choice, borrowing, and capital, Staff Reports 305, Federal Reserve Bank of New York. (accessed March 18, 2019) https://www.newyorkfed.org/medialibrary/media/research/staff_reports/sr305.pdf

Murphy, Kevin J. (2013). Executive compensation: Where we are, and how we got there. In Handbook of the Economics of Finance, vol. 2, pp. 211-356. Elsevier, North Holland.

Noe, Thomas H., Michael J. Rebello, and Larry D. Wall (1996). Managerial rents and regulatory intervention in troubled banks. Journal of Banking \& Finance 20, no. 2: 331-350.

Tett, Gillian (2009). What bankers can learn from Chelsea football club, Financial Times, September 11.

Thanassoulis, John (2012). The case for intervening in bankers' pay. The Journal of Finance 67, no. 3: 849-895.

Thanassoulis, John (2014). Bank pay caps, bank risk, and macroprudential regulation. Journal of Banking \& Finance 48: 139-151.

Tzioumis, K., \& Gee, M. (2013). Nonlinear incentives and mortgage officers’ decisions. Journal of Financial Economics, 107(2), 436-453. Google Scholar

Tung, Frederick and Wang, Xue (2013). Bank CEOs, Inside Debt Compensation, and the Global Financial Crisis Boston Univ. School of Law Working Paper No. 11-49. (accessed March 18, 2019): https://ssrn.com/abstract=1570161 or http://dx.doi.org/10.2139/ssrn.1570161

Van Bekkum, Sjoerd (2016). Inside debt and bank risk. Journal of Financial and Quantitative Analysis 51, no. 2: 359-385. 
Wall, Larry D. (2018) Some Financial Regulatory Implications of Artificial Intelligence. Journal of Economics and Business, 100(C), 55-63. 